\title{
METODE KUBUS RINGKASAN TAKSONOMI BLOOM BERBASIS MIND MAPPING UNTUK MENINGKATKAN HIGHER-ORDER THINGKING SKILL (HOTS) GUNA PENGEMBANGAN LITERASI MATEMATIKA DAN MENDUKUNG KECAKAPAN ABAD 21
}

\author{
Albertus Tuhu Setyo Nugroho* \\ Universitas Negeri Yogyakarta \\ *albertus729@gmail.com
}

Dikirim: 13 Desember 2019. Diterima: 23 Januari 2020. Dipublikasikan: 31 Januari 2020

\begin{abstract}
ABSTRAK
Kemampuan berpikir tingkat tinggi ini biasanya diperlukan untuk memecahkan permasalahan dan persoalan yang sifatnya abstrak dan memerlukan pemahaman secara mendalam, salah satunya adalah matematika. Namun kenyataannya dari fakta yang ada sangat disayangkan, kemampuan matematika di Indonesia masih tergolong rendah. Pada hakikatnya Higher-Order Thinking Skills (HOTS) sebagai suatu pemikiran yang terjadi pada tingkat tinggi dalam suatu proses kognitif. Maka dari itu tujuan dari penulisan penelitian ini yaitu untuk mengetahui pengaruh penerapan penerapan dan pengaruh penerapan metode Kubus Ringkasan Taksonomi Bloom berbasis Mind Mapping pada pembelajaran matematika guna meningkatkan Higher-Order Thinking Skill (HOTS). Metode penelitian dan desain penelitian ini menggunakan studi literatur dan eksperimen. Data dikumpulkan menggunakan metode kepustakaan, metode dokumentasi, dan metode tes. Kemudian data dianalisis secara kualitatif dan kuantitatif. Berdasarkan hasil analisis diperoleh bahwa terdapat perbedaan rata-rata hasil belajar antara kelompok kontrol dengan kelompok eksperimen yang menerapkan metode Kubus Ringkasan Taksonomi Bloom berbasis Mind Mapping terlihat bahwa nilai sig. (2-tailed) sebesar 0,00 $<0,05$. Sedangkan penerapan metode Kubus Ringkasan Taksonomi Bloom berbasis Mind Mapping ini terdiri dari tiga tahap yaitu persiapan alat dan bahan, membuat, dan menggunakan dalam pembelajaran matematika.
\end{abstract}

Kata kunci: Higher-Order Thinking Skill, Literasi Matematika, Mind Mapping.

\begin{abstract}
The ability to think at a higher level is usually needed to solve problems and problems that are abstract and require deep understanding, one of which is mathematics. But the reality of the facts is very unfortunate, mathematical ability in Indonesia is still relatively low. In essence High Order Thinking Skills (HOTS) as a thought that occurs at a high level in a cognitive process. Therefore the purpose of writing this scientific paper is to find out the application and influence of the application of the Mind Mapping-based Bloom Cubic Summary method to mathematics learning to improve High Order Thinking Skills (HOTS). The method of writing this paper uses literature studies and experiments. Data was collected using the library method, documentation method, and test method. Then the data are analyzed qualitatively and quantitatively. Based on the results of the analysis, it was found that there was an average difference between the control group and the experimental group that applied the Mind Mappingbased Bloom Cubic Summary method that shows the sig value. (2-tailed) of $0.00<0.05$. While the application of Mind Mapping based Bloom's Taxonomic Summary method consists of three stages, namely the preparation of tools and materials, making, and using in learning mathematics.
\end{abstract}

Keywords: High Order Thinking Skill, Mathematical Literacy, Mind Mapping. 


\section{Pendahuluan}

Kemampuan berpikir tingkat tinggi ini biasanya diperlukan untuk memecahkan permasalahan dan persoalan yang sifatnya abstrak dan memerlukan pemahaman secara mendalam, salah satunya adalah matematika. Matematika memiliki peranan penting dalam berbagai disiplin dan mengembangkan daya pikir manusia untuk memecahkan masalah. Oleh karena itu, matematika dapat membuat peserta didik berpikir logis, analisis, kritis dan kreatif. Namun kenyataannya dari fakta yang ada sangat disayangkan, kemampuan matematika di Indonesia masih tergolong rendah. Pada hakikatnya High Order Thinking Skills (HOTS) sebagai suatu pemikiran yang terjadi pada tingkat tinggi dalam suatu proses kognitif.

Salah satu strategi untuk mengatasi hal tersebut diperlukan sebuah inovasi media pembelajaran yang menarik dan menyenangkan sehingga siswa akan merasa bahwa pelajaran matematika adalah pelajaran yang menarik dan tidak membosankan. Sehingga siswa akan benar-benar paham akan materi pelajaran yang sedang disampaikan oleh guru. Salah satu upaya untuk membuat pelajaran matematika menjadi menarik dan tidak membosankan adalah dengan menggunakan metode pembelajaran yang inovatif, yakni Kubus Ringkasan Taksonomi Bloom. Menurut Wormeli (2011: 65) guru dapat menggunakan taksonomi Bloom tentang ranah kognitif dalam berbagai cara untuk membantu siswa meringkas dan berinteraksi dengan hal yang mereka telah pelajari.

Berdasarkan permasalahan di atas peneliti akan memanfaatkan metode tersebut untuk meningkatkan kemampuan berpikir siswa dengan penambahan metode mind mapping. Metode mind mapping dipilih oleh peneliti sebagai pelengkap metode Kubus Ringkasan Taksonomi Bloom karena menurut Jumanto (2010) mengemukakan bahwa untuk anak-anak, peta pikiran (mind mapping) memiliki manfaat yaitu: membantu dalam mengingat, mendapatkan ide, menghemat waktu, berkonsentrasi, mendapatkan nilai yang lebih bagus, mengatur pikiran dan hobi, media bermain, bersenang-senang dalam menuangkan imajinasi yang tentunya memunculkan kreativitas, sehingga metode Kubus Ringkasan Taksonomi Bloom berbasis Mind Mapping akan benar-benar menjadi metode yang bisa digunakan untuk mengefektifkan pembelajaran sehingga akan meningkatkan kemampuan berpikir siswa terutama dalam pembelajaran matematika. Lebih lanjut, DePorter (2010: 225) mengungkapkan bahwa metode Mind Mapping membantu siswa mengingat perkataan dan bacaan, meningkatkan pemahaman terhadap materi, membantu mengorganisasi materi, dan memberikan wawasan baru.

Tujuan yang ingin dicapai dalam penelitian ini, yaitu untuk mengetahui pengaruh penerapan metode Kubus Ringkasan Taksonomi Bloom berbasis Mind Mapping pada pembelajaran matematika guna meningkatkan High Order Thinking Skill (HOTS).

\section{Metode Penelitian}

Metode penelitian ini menggunakan studi literatur dan eksperimen. Tujuan studi literatur ini adalah sebagai dasar pembentukan rencana penulisan awal. Sedangkan untuk mengetahui pengaruh penerapan metode Kubus Ringkasan Taksonomi Bloom berbasis Mind Mapping digunakan metode eksperimen. bentuk eksperimen yang digunakant adalah true eksperimen menggunakan desain penelitian Posttest-Only Control Group Design (Sugiyono, 2017: 76). Mind Mapping adalah cara termudah untuk menempatkan informasi kedalam otak dan mengambil informasi keluar dari otak. Mind Mapping adalah cara mencatat yang kreatif, efektif, dan secara harfiah akan memetakan pikiran kita. Mind Mapping juga sangat sederhana (Buzan, 2012: 4). Dalam penelitian ini soal tes hasil belajar berbentuk soal uraian dengan jumlah soal adalah 5 soal yang disusun sesuai dengan taksonomi Bloom revisi yaitu pada aspek HOTS (C4-C6).

Metode analisis data dalam penelitian ini menggunakan dua pendekatan, yaitu metode analisis kualitatif ini digunakan untuk mengetahui penerapan metode Kubus Ringkasan Taksonomi Bloom berbasis Mind Mapping dan untuk mengetahui kelebihan serta kekurangan dilakukan menggunakan analisis SWOT. Dalam penelitian ini, peneliti menggunakan teknik analisis data dengan pendekatan metode kuantitatif deskriptif. Dimana dalam pengolahan data secara kuantitatif ini mengolah data nilai hasil posttest dengan menggunakan teknik independent sample t- test. 
Waktu dan Tempat Penelitian

Penelitian eksperimen yang dilakukan di SMAN 1 Karangmojo pada tahun pelajaran 2018/2019.

Target/Subjek Penelitian

Penulis menggunakan populasi seluruh kelas $\mathrm{X}$ MIA (sejumlah empat kelas) yang keseluruhannya diambil sampel menggunakan teknik random sampling, didapat X MIA 3 sebagai kelas eksperimen dan kelas X MIA 2 sebagai kelas kontrol.

Data, Intrumen, dan Teknik Pengumpulan Data

Pada penelitian ini, penulis menggunakan yang sesuai dengan maksud dan tujuan penyusunan peelitian ini yaitu metode kepustakaan, metode dokumentasi serta metode tes.

Teknik Analisis Data

Metode analisis data dalam penelitian ini menggunakan dua pendekatan, yaitu:

1. Pendekatan kualitatif

Metode analisis kualitatif ini digunakan untuk mengetahui penerapan metode Kubus Ringkasan Taksonomi Bloom berbasis Mind Mapping dan untuk mengetahui kelebihan serta kekurangan dilakukan menggunakan analisis SWOT.

2. Pendekatan Kuantitatif

Dalam penelitian ini, peneliti menggunakan teknik analisis data dengan pendekatan metode kuantitatif deskriptif. Dimana dalam pengolahan data secara kuantitatif ini mengolah data nilai hasil posttest. Langkah-langkah dari analisis data dengan pendekatan kuantitatif deskriptif ini sebagai berikut:

a. Statistik deskriptif

Data yang telah diperoleh kemudian di analisis menggunakan analisis statistik deskriptif, yaitu menghitung nilai rata-rata kelompok, minimum dan maksimum, standar deviasi dengan menggunakan program SPSS 15.0 for Windows.

b. Uji Prasyarat Analisis Data.

Sebelum data digunakan untuk menguji hipotesis, data yang sudah terkumpul dan dianalisis dengan statistik deskriptif kemudian dianalisis dengan uji normalitas dan homogenitas data.

c. Uji Perbedaan Dua Rata-rata

Teknik statistik yang digunakan adalah teknik independent sample t- test.

\section{Hasil Penelitian dan Pembahasan}

Hasil penelitian disajikan dalam bentuk grafik, tabel, atau deskriptif. Analisis dan interpretasi hasil ini diperlukan sebelum dibahas.

1. Pengaruh Penerapan Metode Kubus Ringkasan Bloom berbasis Mind Mapping

a. Statistik Deskriptif Data Posttest

Soal posttest diberikan setelah rangkaian kegiatan pembelajaran (eksperimen), soal posttest ini digunakan untuk mengetahui pengetahuan siswa setelah mengikuti proses pembelajaran yang diberi perlakuan berupa penerapan metode Kubus Ringkasan Taksonomi Bloom berbasis MinD Mapping pada kelas eksperimen dan menggunakan metode pembelajaran konvensional pada kelas kontrol.

Tabel 1. Statistik Deskriptif Nilai Posttest

\begin{tabular}{lccccc}
\hline Kelas & N & Min & Max & Mean & Std. Deviasi \\
\hline Eksperimen & 29 & 68 & 88 & 76.14 & 6.093 \\
\hline
\end{tabular}




\begin{tabular}{llllll}
\hline Kontrol & 28 & 52 & 76 & 63.86 & 5.275
\end{tabular}

Pada Tabel 1. terlihat bahwa skor tertinggi posttest kelas eksperimen adalah 88, skor terendahnya adalah 68 skor rata-rata kelas adalah 76.14 dengan standar deviasi sebesar 6.093. Sedangkan skor tertinggi posttest kelas kontrol adalah 76 dan skor terendahnya adalah 52. Skor rata-rata kelas adalah 63.86 dengan standar deviasi sebesar 5.274.

b. Uji Prasyarat Penelitian

1) Uji Normalitas

Pengujian normalitas menggunakan statistik uji Kolmogorov-Smirnov dengan bantuan program SPSS 15.0. Berikut adalah hasil uji normalitas nilai posttest.

Tabel 2. Hasil Uji Normalitas Nilai Posttest

\begin{tabular}{|c|c|c|c|c|}
\hline Kelas & Z & Sig. (P) & A & Kesimpulan \\
\hline Eksperimen & 0.993 & 0.278 & \multirow{2}{*}{0.05} & Normal \\
\hline Kontrol & 1.241 & 0.092 & & Normal \\
\hline
\end{tabular}

2) Uji Homogenitas

Uji homogenitas varians menggunakan program SPSS 15.0 for Windows. Berikut disajikan hasil dari uji homogenitas untuk nilai posttest dalam bentuk tabel.

Tabel 3. Hasil Uji Homogenitas Nilai Posttest

\begin{tabular}{llrrrr}
\hline & $\begin{array}{c}\text { Levene } \\
\text { Statistic }\end{array}$ & df1 & df2 & \multicolumn{1}{c}{ Sig. } \\
\hline Posttest & Based on Mean & 1.502 & 1 & 55 & .225 \\
\hline & Based on Median & 1.001 & 1 & 55 & .321 \\
\hline $\begin{array}{l}\text { Based on Median and with } \\
\text { adjusted df }\end{array}$ & 1.001 & 1 & 54.999 & .321 \\
\hline Based on trimed Mean & 1.568 & 1 & 55 & .216
\end{tabular}

c. Uji Perbedaan Dua Rata-rata (Uji Pihak Kanan)

Uji perbedaan dua rata-rata ini dilakukan untuk mengetahui adanya peningkatan hasil belajar setelah siswa diberi perlakuan yang menunjukkan metode tersebut terbukti efektif selama pembelajaran dilakukan. Untuk mengetahui terjadinya peningkatan hasil belajar siswa yang diberikan treatment, maka digunakan rumus t-test (independent sample t-test) dalam hal ini peneliti menggunakan bantuan software SPSS 15.0 dengan hasil sebagai berikut. Hipotesis statistik:

$\mathrm{H} 0 \quad: \mu_{1} \leq \mu_{2}$ dan $\mathrm{Ha} \quad: \mu_{1}>\mu_{2}$

Tabel 4. Hasil Perhitungan Uji t

\begin{tabular}{llllll}
\hline Kelas & Df & $\begin{array}{l}\text { Sig. }(2- \\
\text { tailed) }\end{array}$ & $\alpha$ & thitung & $\begin{array}{c}\text { ttab } \\
\text { el }\end{array}$ \\
\hline Eksperimen & & & \\
\hline
\end{tabular}




$\begin{array}{llllll}\text { Kontrol } & 55 & 0.00 & 0.05 & 8.123 & 1.671\end{array}$

Pada $\alpha=5 \%$ dengan $\mathrm{dk}=29+28-2=55$ diperoleh ttabel $=1.673$. Dengan perhitungan $t$-test diperoleh thitung $=8.123$ dan ttabel $=1.673$ dan terlihat bahwa nilai sig. (2-tailed) sebesar $0,00<$ 0,05 . Jadi dibandingkan antara thitung dan tabel maka tt lhitung $>$ ttabel sehingga di dapat bahwa $\mathrm{H} 0$ ditolak dan $\mathrm{Ha}_{\mathrm{a}}$ diterima. Ini menunjukkan bahwa adanya peningkatan hasil belajar setelah siswa diberi perlakuan yang menunjukkan metode tersebut terbukti efektif selama pembelajaran dilakukan.Penerapan Metode Kubus Ringkasan Taksonomi Bloom berbasis Mind Mapping

d. Implementasi Metode Kubus Ringkasan Taksonomi Bloom berbasis Mind Mapping Pada Pembelajaran Matematika

Berikut ini adalah langkah-langkah penggunaan metode Kubus Ringkasan Taksonomi Bloom berbasis Mind Mapping pada pembelajaran.

Tabel 5. Langkah-langkah Penerapan metode Kubus Ringkasan Taksonomi Bloom berbasis Mind Mapping

Tahap Aktivitas Peserta Didik

Tahap 1 1. Peserta didik duduk dalam kelompok yang telah ditentukan.

2. Peserta didik memperhatikan guru saat menyajikan pelajaran secara garis besar dan memberikan topik-topik penting dalam materi yang akan dipelajari.

3. Setiap kelompok menerima materi diskusi yang sama.

4. Peserta didik melaksanakan arahan guru agar kelompok lebih aktif dalam berdiskusi membahas materi yang diberikan.

Tahap 2 5. Peserta didik diminta untuk membuat rangkuman sesuai dengan indikator tingkatan Taksonomi Bloom. Untuk tingkatan taksonomi dan kata kerja operasional dapat dilihat pada lampiran.

6. Setelah membuat rangkuman yang sesuai dengan indikator tingkatan Taksonomi Bloom, peserta didik membuat mind mapping sesuai ringkasan yang telah dibuat berdasarkan tingkatan Taksonomi Bloom. Untuk pembuatan mind mapping tidak ada ketentuan khusus, namun harus disesuaikan dengan jumlah tingkatan Taksonomi Bloom yaitu ada 6 tingkatan.

Tahap 3 7. Salah satu kelompok diminta maju ke depan untuk menyampaikan hasil ringkasanya.

8. Peserta didik menjawab pertanyaan guru dan kelompok lain dan memberikan tanggapan.

9. Peserta didik menerima penguatan dan menyimpulkan materi yang sudah dipelajari dengan metode Kubus Ringkasan Taksonomi Bloom berbasis Mind Mapping.

Pembelajaran menggunakan metode Kubus Ringkasan Taksonomi Bloom berbasis Mind Mapping pada kelas eksperimen dilaksanakan tiga kali pertemuan. Peneliti memperlihatkan dan menjelaskan tentang prosedur penggunaan metode Kubus Ringkasan Taksonomi Bloom berbasis Mind Mapping yang akan digunakan dalam proses pembelajaran. Ini merupakan tahap awal sebelum pembelajaran dimulai atau pra pembelajaran.

Dalam penelitian ini peneliti menambahkan metode Mind Mapping pada kubus tersebut. Hal ini dilakukan oleh peneliti karena Mind Mapping membantu siswa dalam meringkas suatu mata pelajaran terutama Matematika. Metode Kubus Ringkasan Taksonomi Bloom berbasis Mind 
Mapping ini digunakan sebagai media presentasi juga dapat digunakan untuk membantu meringkas dan menganalisis soal secara mendalam. Berikut peneliti jelaskan prosedur pembuatan dan penggunaan metode Kubus Ringkasan Taksonomi Bloom berbasis Mind Mapping.

1) Langkah Pertama (Persiapan alat dan bahan)

Langkah pertama adalah mempersiapkan bahan dan alat yang akan digunakan dalam membuat metode Kubus Ringkasan Taksonomi Bloom berbasis Mind Mapping. Untuk bahan terdiri dari kertas karton, lem, double tipe, dan kertas HVS, sedangkan alatnya terdiri dari gunting dan cutter. Alat dan bahan tersebut dipilih oleh peneliti karena sangat mudah didapatkan dan harganya murah atau bisa bisa juga menggunakan bahan lain yang lebih kuat untuk media kubusnya.

2) Langkah Kedua (Membuat)

Langkah kedua adalah membuat media Kubus Ringkasan Taksonomi Bloom berbasis Mind Mapping. Untuk ukuran disesuaikan dengan kebutuhan. Dalam penelitian ini peneliti menggunakan ukuran $30 \mathrm{~cm}$ setiap sisinya. Ukuran ini dipilih agar media tersebut dapat terlihat oleh siswa pada saat digunakan untuk presentasi. Namun jika hanya digunakan untuk presentasi kelompok kecil dan dipajang di depan kelas bisa menggunakan ukuran 12,5 $\mathrm{cm}$ setiap sisinya.

3) Langkah Ketiga (Menggunakan)

Pada langkah ketiga ini peneliti akan menjelaskan prosedur penggunaan metode Kubus Ringkasan Taksonomi Bloom berbasis Mind Mapping sebagai media presentasi dan sebagai media untuk mengerjakan soal secara kreatif. Pada langkah ketiga ini peneliti akan menjelaskan prosedur penggunaan metode Kubus Ringkasan Taksonomi Bloom berbasis Mind Mapping sebagai media presentasi di depan kelas. Pada langkah ketiga ini terdiri dari beberapa sub langkah, yaitu:

a) Rangkumlah materi sesuai dengan materi pembelajaran yang sedang diajarkan di kertas HVS menggunakan metode Mind Mapping, untuk ukuran kertas sesuaikan dengan ukuran kubus. Pada proses merangkum ini juga harus memperhatikan petunjuk, karena harus sesuai dengan tingkatan taksonomi (C1-C6);

b) Gunakan bolpoint warna dan gambar untuk memberikan kesan menarik pada Mind Mapping anda;

c) Tempelkan dan sesuaikan hasil ringkasan anda dengan tingkatan taksonomi Bloom. Setelah selesai meringkas, tempelkan ringkasan anda menggunakan double tipe pada sisi-sisi metode Kubus Ringkasan Taksonomi Bloom berbasis Mind Mapping sesuai dengan tingkatan taksonominya;

d) Setelah tertempel dengan rapi dan sesuai dengan tingkatan taksonominya, metode Kubus Ringkasan Taksonomi Bloom berbasis Mind Mapping siap digunakan sebagai media untuk presentasi di depan kelas.

e) Untuk presentasi di depan kelas bisa menggunakan kubus ukuran $30 \mathrm{~cm} \mathrm{x}$

$30 \mathrm{~cm}$. Sedangkan untuk presentasi di dalam kelompok kecil bisa menggunakan kubus ukuran $12,5 \mathrm{~cm} \times 12,5 \mathrm{~cm}$.

e. Analisis SWOT

Analisis SWOT dilakukan untuk mengetahui kelayakan metode Kubus Ringkasan Taksonomi Bloom berbasis Mind Mapping jika diterapkan pada pembelajaran guna meningkatkan High Order Thinking Skill (HOTS) dengan menggunakan analisis SWOT (Strength, Weakness, Opportunity, dan Threat). Adapun analisis metode metode Kubus Ringkasan Taksonomi Bloom berbasis Mind Mapping adalah sebagai berikut.

1) Kekuatan (Strenght)

a. Merupakan metode baru yang inovatif untuk meringkas.

b. Dapat meningkatkan kemampuan berpikir kritis dan kreativitas peserta didik. 
c. Dapat diterapkan di semua mata pelajaran.

d. Dapat dipadukan atau diitegrasikan dengan semua model pembelajaran terutama model pembelajaran yang mengacu pada student learning center.

2) Kelemahan (Weakness)

Membutuhkan waktu yang lama untuk mengenalkan metode Kubus

Ringkasan Taksonomi Bloom berbasis Mind Mapping kepada peserta didik maupun pendidik.

3) Peluang (Opportunity)

a. Semakin meningkatnya mminat baca peserta didik.

b. Semakin tingginya kebutuhan akan inovasi metode dan model pembelajaran.

c. Dapat meningkatkan minat membaca dan menulis peserta didik, karena kegiatan meringkas membutuhkan kemampuan membaca dan menulis yang baik.

4) Ancaman (Threat)

a. Peserta didik merasa cepat bosan dan jenuh.

b. Peserta didik lebih tertarik untuk menggunakan metode meringkas yang lain.

\section{Simpulan dan Saran}

Simpulan

Berdasarkan hasil analisis diperoleh bahwa terdapat perbedaan rata-rata hasil belajar antara kelompok kontrol dengan kelompok eksperimen yakni penerapan metode Kubus Ringkasan Taksonomi Bloom berbasis Mind Mapping lebih efektif dibandingkan kelas kontrol (tanpa perlakuan). Hal ini dapat dilihat bahwa nilai sig. (2-tailed) sebesar $0,00<0,05$. Sedangkan penerapan metode Kubus Ringkasan Taksonomi Bloom berbasis Mind Mapping ini terdiri dari tiga tahap yaitu persiapan alat dan bahan, membuat, dan menggunakan dalam pembelajaran matematika.

Saran

Berdasarkan hasil penelitian, diketahui bahwa nilai persentase ketuntasan klasikal belum memenuhi $80 \%$, hal ini bisa dijadikan kajian pada penelitian selanjutnya. Selain itu pada penelitian ini metode Taksonomi Kubus Ringkasan Bloom berbasis Mind Mapping belum di validasi ahli, ada baiknya untuk di validasi terlebih dahulu. Kepada pihak sekolah hendaknya meningkatkan kompetensi para guru, khususnya dalam memanfaatkan metode pembelajaran, mengingat dalam penelitian ini telah membuktikan bahwa penggunaan metode pembelajaran sangat efektif terhadap hasil belajar siswa. Dengan penelitian ini diharpkan para guru matematika lebih memperhatikan tingkat kemampuan berpikir tingkat tinggi siswa dengan cara mengembangan pembelajaran yang kreatif melalui penggunaan media pembelajaran yang inovatif sehingga penyampaian materi yang diajarkan di kelas bisa tercapai secara maksimal. Selain itu juga diharapkan untuk para pendidik supaya menggunakan media ini untuk diterapkan pada mata pelajaran lainnya.

\section{Daftar Pustaka}

Buzan, T. (2008). Buku Pintar Mind Map. Jakarta: Gramedia Pustaka Utama. Deporter, B. (2010). Quantum Teaching. Bandung: KAIFA.

Jumanto. (2010). Peningkatan Kemampuan Menulis Cerita Melalui Metode (Mind Mapping) pada Siswa Kelas IV SD Negeri Sondakan No. 11 Surakarta. Skripsi. Surakarta: Tidak Diterbitkan. 
Range: Jurnal Pendidikan Matematika Vol. 1 No. 2 Tahun 2020 Albertus Tuhu Setyo Nugroho

Sugiyono. (2017). Metode Penelitian Kuantitatif, Kualitatif, dan R\&D. Bandung: Alfabeta.

Wormeli, R. (2011). Meringkas Mata Pelajaran: 50 Teknik Untuk Meningkatkan Pembelajaran Siswa. Jakarta: Erlangga. 